\title{
Peningkatan Kemampuan Menulis Cerpen dengan Model Pembelajaran Mind Mapping pada Siswa Kelas IX
}

\author{
Ikbal $^{1^{*}}$ \\ ${ }^{1}$ Jurusan Pendidikan Bahasa dan Sastra Indonesia, Universitas Pendidikan Ganesha, Singaraja, Indonesia
}

\section{ART I CLE I N F O}

Article history:

Received July 16, 2021

Revised July 20, 2021

Accepted October 20, 2021

Available online November 25, 2021

Kata Kunci:

Menulis Cerpen, Model Mind

Mapping

Keywords:

Short Story Writing, Mind Mapping Mode

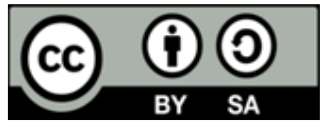

This is an open access article under the CC BY-SA license.

Copyright $(2021$ by Author. Published by Universitas Pendidikan Ganesha.

\begin{abstract}
A B S T R A K
Pembelajaran menulis lebih banyak disajikan dalam bentuk teori, tidak banyak melakukan praktik menulis. Hal ini mengakibatkan kurangnya kebiasaan menulis siswa, sehingga mereka sulit menuangkan ide mereka dalam bentuk tulisan. Penelitian ini bertujuan untuk meningkatkan kemampuan menulis cerpen siswa di kelas IX dengan menerapkan model Pembelajaran Mind Mapping (Peta Pikiran). Jenis penelitian ini adalah penelitian tindakan kelas dengan subjek penelitian seluruh siswa kelas IX yang berjumlah 37 orang. Instrumen yang digunakan dalam mengumpulkan data penelitian adalah tes uraian yang sama untuk pretes dan postes, sebanyak 1 soal. Kriteria keberhasilan penelitian tindakan kelas ini adalah jumlah siswa yang memenuhi atau lebih dari KKM minimal sebesar $85 \%$. Hasil penelitian pada siklus I, nilai posttes yang diperoleh adalah 22 siswa (59,45\%) yang mencapai ketuntasan belajar (KKM) dengan nilai rata - rata 73,51. Setelah dilakukan refleksi dari siklus I dan beberapa perbaikan, maka pada siklus II, nilai postes mengalami peningkatan yaitu 32 siswa $(86,48 \%)$ yang mencapai ketuntasan belajar (KKM) dengan nilai rata - rata 84,32. Hasil penghitungan diperoleh kektuntasan klasikal pada siklus kedua lebih besar dari ketuntasan klasikal minimal yaitu $86,48 \%>85 \%$. Dapat disimpulkan bahwa penerapan model pembelajaran mind mapping (peta pikiran) dapat meningkatkan hasil belajar siswa. Implikasi penelitian ini diharapkan guru dapat menerapkan model pembelajaran ini pada proses pembelajaran.
\end{abstract}

A B S T RACT

Learning to write is mainly presented in theory, not much writing practice. It causes students to lack writing habits, so it is problematic for them to express their ideas in written form. This study aims to determine whether the Mind Mapping Learning model improves students' short story writing skills in class IX. This type of research is classroom action research with the subject of this research, all class $I X$ students totaling 37 people. The research instrument in collecting data was the exact description test for pretest and posttest, with 1 question. The analytical technique used in classical completeness, namely the number of students who meet or more than the minimum KKM of $85 \%$. The results of the research in the first cycle, the Posttest scores obtained were 22 students (59.45\%) who achieved learning completeness (KKM) with an average value of 73.51. After reflecting on the first cycle and several improvements, in the second cycle, the Posttest score increased, namely 32 students $(86.48 \%)$ who achieved learning completeness (KKM) with an average value of 84.32. The calculation results obtained classical completeness in the second cycle is greater than the minimum classical completeness that, is $86.48 \%>85 \%$. It can be concluded that the application of the Mind mapping Learning model can improve student learning outcomes. This research implies that teachers are expected to be able to apply this learning model to the learning process.

\section{PENDAHULUAN}

Pembelajaran menulis merupakan salah satu pembelajaran yang memerlukan perhatian khusus baik dari guru mata pelajaran maupun pihak-pihak yang terkait dalam penyusunan kurikulum pembelajaran (Andayani \& -, 2018; Nugraheni, 2019). Kedudukan pelajaran menulis di sekolah- sekolah sangat diperlukan. Keterampilan menulis ini perlu diajarkan sejak awal karena sangat bermanfaat bagi peningkatan aspek intelektual, terutama keterampilan berpikir (Sunarsih, 2016; Susilo \& Ramdiati, 2019; 
Yamtinah et al., 2021). Siswa SMP dituntut agar mempunyai kemampuan menulis dengan memerhatikan berbagai aspek yang cukup kompleks. Misalnya, pilihan bahasa, penguasaan kalimat, dan pengembangan paragraf. Hal ini berarti bahwa perkembangan menulis siswa SMP masih perlu diperhatikan. Mengingat pentingnya aktivitas menulis tersebut, keterampilan menulis itu sangat perlu ditingkatkan agar siswa menjadi terampil menulis (Andayani \& -, 2018; Fitriani \& Nurchasanah, 2017; Suastika, 2019). Proses pembelajaran yang sengaja dilakukan untuk keperluan itu. Salah satu keterampilan menulis tersebut adalah menulis cerpen. Pembelajaran keterampilan menulis cerpen ini bertujuan agar siswa dapat mengekspresikan gagasan, pendapat, dan pengalamannya dalam bentuk sastra tertulis yang kreatif (Dini Rahma Diani, Nurhayati, 2019; Nuzulia, 2016). Pembelajaran menulis cerpen di sekolah adalah pembelajaran yang menuntut peserta didik untuk berpikir secara kreatif (Maulina et al., 2021). Peserta didik perlu diberi kesempatan kreatif agar dapat menuangkan apa yang ada dipikirannya ke dalam bentuk cerpen. Untuk mencapai keberhasilan pembelajaran akan sangat bergantung pada guru dalam mengemas kegiatan belajar mengajar menjadi menyenangkan, bermakna, dan mampu mengembangkan potensi peserta didik (Al Hakim, 2021; Satriana et al., 2021). Hal itu dapat dicerminkan dari ketercapaian tujuan pembelajaran yang hendak dicapai. Guru harus dapat membuat perencanaan pembelajaran dengan matang. Selain itu, guru juga hendaknya dapat memilih dan menggunakan strategi yang tepat.

Saat ini pembelajaran menulis lebih banyak disajikan dalam bentuk teori, tidak banyak melakukan praktik menulis (Azis, 2019; Rahmadani, 2019). Hal ini mengakibatkan kurangnya kebiasaan menulis siswa, sehingga mereka sulit menuangkan ide mereka dalam bentuk tulisan. Keterampilan menulis yang tidak diimbangi dengan praktik menjadi salah satu faktor kurang terampilnya siswa dalam menulis. Siswa pada sekolah menengah pertama seharusnya sudah lebih bisa mengekspresikan gagasan, pikiran, dan perasaannya secara tertulis. Namun pada kenyataannya, kegiatan menulis belum sepenuhnya terlaksana. Menyusun suatu gagasan, pendapat, dan pengalaman menjadi suatu rangkaian berbahasa tulis yang teratur, sistematis, danlogis bukan merupakan pekerjaan mudah, melainkan pekerjaan yang memerlukan latihan terus-menerus. Tidak berlebihan jika dikatakan bahwa kemampuan menulis merupakan kemampuan yang kompleks, yang menuntut sejumlah pengetahuan dan keterampilan. Penyebab lain dari terbatasnya siswa dalam kemampuan menulis adalah guru kurang kreatif dalam memilih bahan ajar, metode, dan media pembelajaran. Pendekatan tradisional masih digunakan guru dalam pembelajaran menulis. Proses pembelajaran yang dilakukan selama ini hanya berkisar penyampaian materi dengan ceramah dan mencatat, dengan demikian siswa kurangmendapatkan praktik secara langsung. Hal tersebut membuat siswa cenderung pasif dan merasa bosan dengan proses pembelajaran. Berdasarkan hasil observasi dan tes awal yang telah dilakukan oleh peneliti di kelas IX 15 SMP Negeri 2 Singaraja Kabupaten Buleleng dapat diketahui bahwa kemampuan siswa dalam menulis cerpen masih sangat rendah. Siswa kurang antusias dan kurang tertarik dengan pembelajaran menulis cerpen. Banyak cerpen yang dihasilkan oleh siswa yang tidak sesuai dengan harapan. Tulisan tidak sesuai dengan alur cerita yang ditulis dengan hasil tes awal hanya 13 dari 37 siswa yang lulus atau memenuhi KKM. Faktor kesulitan tersebut disebabkan oleh beberapa hal, yaitu siswa kurang tertarik dengan materi yang diberikan oleh guru, siswa kesulitan untuk mengembangkan ide cerita menjadi sebuah cerita, siswa menganggap bahwa pembelajaran menulis sulit untuk dilakukan, dan siswa tidak berbakat menulis cerpen.

Solusi yang dapat diterapkan yaitu kreativitas guru sangat dibutuhkan dalam memilih media dengan metode yang tepat untuk siswa. Guru dapat melakukan pengembangan keterampilan menulis siswa dengan media pembelajaran. Bahan ajar, metode, dan media pembelajaran yang dipilih sebaiknya mempertimbangkan masalah kebutuhan, minat, dan perhatian siswa serta lingkungan kehidupan mereka. Metode pembelajaran sangat perlu dihadirkan untuk meningkatkan keterampilan menulis siswa. Salah satu metode yang digunakan dalam meningkatkan kemampuan keterampilan menulis cerpen adalah metode mind mapping. Metode pembelajaran mind map memungkinkan peserta didik mengeluarkan gagasannya dan mencatatnya secara kreatif dalam bentuk mind map (peta pikiran) (Astuti et al., 2013; Buran \& Filyukov, 2015). Peta pikiran adalah diagram yang digunakan untuk mewakili kata-kata, ide, dan konsep lainnya yang disusun di sekitar ide utama (Putra et al., 2017). Melalui mind map peserta didik memetakan konsepkonsep ilmu yang diperoleh dari buku pada selembar kertas dalam bentuk simbolsimbol, kata-kata, gambar, serta garis-garis dengan berbagai warna sehingga dalam hal ini peserta didik menciptakan media belajar sendiri. Pemetaan pikiran atau biasa dikenal dengan istilah mind mapping adalah salah satu metode pembelajaran yang dapat digunakan untuk mengatasi masalah tersebut. Bermula dari kesulitan siswa dalam memahami dan menerapkan unsur instrinsik dalam cerpen yang dibuatnya serta kesulitan dalam mengembangkan ide cerita dipilihlah metode pemetaan pikiran (mind mapping). Metode ini merupakan metode yang efektif untuk meningkatkan kemampuan menulis. Dalam metode pemetaan pikiran (mind mapping) tersebut, pertama-tama siswa menuliskan satu kata kunci dari tema yang dipilih di tengah kertas (Astuti et al., 2013; Boerma et al., 2021; Buran \& Filyukov, 2015). Tema 
tersebut kemudian dijabarkan dalam ranting- ranting berupa unsur cerpen yang meliputi alur, penokohan, watak, setting, sudut pandang serta ending cerita yang telah dipilih.

Beberapa temuan penelitian sebelumnya menyatakan metode mind mapping mampu meningkatkan minat, motivasi dan hasil belajar siswa (Astuti et al., 2013; Sulfemi, 2019). Selain itu melalui penerapan metode mind mapping terjadi peningkatan keterampilan berbicara (Febiyanti et al., 2020). Dengan menerapkan metode mind mapping siswa lebih mudah memahami materi konsep (Buran \& Filyukov, 2015; Sartono et al., 2018). Mind mapping juga meningkatkan keaktifan siswa (Merchie \& Keer, 2016; Wu \& Chen, 2018). Materi pembelajaran yang diangkat dalam penelitian ini adalah menulis cerpen. Keterampilan menulis tidak bisa tercipta begitu saja tanpa melaluia proses. Keterampilan itu tumbuh dan berkembang akibat adanya proses yang berulang. Makin sering seseorang berlatih menulis, tentunya semakin terampil ia menulis dan kualitas tulisannya pun akan lebih baik. Model pembelajaran Mind Mapinng dipilih dikarenakan mind mapping adalah salah cara yang efektif dalam memunculkan ide yang terpendam yang dimiliki oleh seseorang. Mind mapping juga berguna untuk mengorganisasikan informasi yang dimiliki. Bentuk diagramnya yang seperti diagram pohon dan percabangannya memudahkan untuk mereferensikan satu informasi kepada informasi yang lain. Penelitian ini bertujuan untuk meningkatkan kemampuan menulis cerpen dengan penerapan model pembelajaran mind mapping pada siswa kelas IX.

\section{METODE}

Jenis penelitian yang digunakan dalam penelitian ini adalah penelitian tindakan kelas (classroom action research). Penelitian tindakan kelas adalah suatu bentuk penelitian yang bersifat reflektif dengan melakukan tindakan-tindakan tertentu agar dapat memperbaiki dan meningkatkan praktik-praktik pembelajaran di kelas secara profesional. Adapun prosedur yang harus dilalui dalam penelitian ini adalah sebagai berikut: a) observasi awal, b) refleksi awal, c) identifikasi masalah, d) analisis masalah, e) perumusan masalah, f) perencanaan tindakan, g) pelaksanaan tindakan, h) observasi hasil tindakan dan i) refleksi. Teknik pengumpulan data yang digunakan dalam penelitian ini terdiri dari pengumpulan data aktivitas dan hasil belajar. Data aktivitas belajar dikumpulkan pada setiap pertemuan pada setiap siklus yang dilakukan oleh peneliti. Sedangkan data hasil belajar dikumpulkan pada pertemuan kedua setiap siklus. Dalam penelitian ini, analisis data yang digunakan untuk menyelesaikan masalah yang disajikan dalam penelitian ini adalah analisis deskriptif yaitu menjelaskan arah perubahan, peningkatan perubahan kemampuan menulis cerpen. Analisis deskriptif bertujuan untuk menggambarkan keadaan siswa terhadap pokok bahasan menulis cerpen dengan melaksanakan observasi untuk mengetahui kemampuan siswa terhadap materi tersebut dan sebagai informasi dalam mengambil pertimbangan, dalam melaksanakan usaha-usaha perbaikan terhadap kelemahan-kelemahan yang ada. Kegiatan penelitian mengharuskan adanya rancangan penelitian agar penelitian ini berjalan dengan efektif dan efisien. Penelitian tindakan kelas ini dilaksanakan sebanyak dua siklus. Setiap siklus terdiri dari dua kali pertemuan, 1 pertemuan dialokasikan waktu sebanyak $2 \times 40$ menit sesuai dengan kurikulum yang terdapat disekolah tentang pembelajaran teknik dasar passing bola basket. Penelitian ini dilakukan pada siswa kelas IX 15 SMP Negeri 2 Singaraja Tahun Pelajaran 2017/2018 yang dilaksanakan pada semester ganjil dengan materi pembelajaran menulis cerpen. Tempat penelitian ini dilaksanakan di ruang kelas SMP Negeri 2 Singaraja.

\section{HASIL DAN PEMBAHASAN}

\section{Hasil}

Pada observasi awal yang dilakukan di kelas IX 15 SMP Negeri 2 Singaraja Tahun Pelajaran 2017/2018 ditemukan data aktivitas dan hasil belajar yang masih rendah. Hal ini terlihat secara klasikal siswa masih belum mampu memenuhi KKM di sekolah yang sebesar 75\%. Pada data aktivitas belajar siswa secara klasikal dalam menulis cerpen baru mencapai 13 siswa yang lulus dari 37 siswa. Hal tersebut bermakna bahwa secara umum siswa belum mampu atau masih kesulitan dalam materi menulis cerpen karena persentase kelulusan siswa baru mencapai 13,35\%. Pada siklus I pertemuan dilaksanakan sebanyak 2 kali pertemuan yang disusun dalamRencana Pelaksanaan Pembelajaran (RPP). Pada tahap ini, guru terlebih dahulu menjelaskan tentang model pembelajaran mind mapping (peta pikiran) yang akan diterapkan di kelas kemudian menjelaskan materi pelajaran yang akan dipelajari dengan singkat. Setelah itu, guru memberikan tes awal sebelum pelaksanaan model pembelajaran mind mapping (peta pikiran) untuk mengetahui tingkat pemahaman siswa tentang materi pelajaran tersebut. Guru membagi siswa ke dalam beberapa kelompok diskusi untuk membahas masalah yang diberikan oleh guru. Dalam diskusi ini, guru memotivasi siswa untuk mengumpulkan informasi yang sesuai dengan masalah, mencari penjelasan atau pengertian dari sumber lain dan mampu memecahkan masalah. Siswa dituntut kritis dan kreatif. 
Pada pertemuan kedua siklus I, dilakukan kembali kegiatan diskusi kelompok untuk membahas masalah yang diberikan oleh guru. Pada pertemuan ini guru lebih memotivasi siswa agar siswa lebih semangat dan aktif dalam kelompoknya. Seperti pertemuan sebelumnya, untuk menghindari siswa ribut, maka guru mengarahkan siswa yang duduk untuk membentuk kelompoknya. Siswa yang sudah dikelompoknya, mendiskusikan dan menuliskannya kemudian mempresentasikan hasil kerja kelompoknya. Setelah kegiatan ini berakhir, guru memberikan tes hasil belajar I tertulis kepada siswa untuk mengetahui perubahan yang terjadi setelah penerapan model pembelajaran mind mapping (peta pikiran).

Berdasarkan hasil pengamatan selama proses pembelajaran berlangsung dapat dilihat bahwa pembelajaran masih dalam kategori cukup dan masih ada beberapa siswa yang memperoleh hasil yang rendah dan tidak tuntas. Oleh karena itu, perlu dilakukan perbaikan. Pada saat diskusi kelompok masih terdapat siswa yang hanya diam dan membiarkan temannya yang berkemampuan lebih mendominasi dalam kelompok, sedangkan siswa tersebut hanya diam dan mencatat hasil diskusi tanpa mau memberi masukan kepada kelompoknya. Hal ini disebabkan oleh beberapa faktor, yaitu siswa yang belum dapat beradaptasi dengan model yang baru diterapkan, sehingga pembelajaran untuk menuntaskan materi pembelajaran tidak terlaksana dengan baik. Di samping itu, masih ada siswa yang kurang menguasai matari pelajaran. Skor rata-rata hasil belajar pada siklus I mencapai 59,45\% mengalami peningkatan dari tes awal (pretest) sebelum penerapan model pembelajaran mind mapping (peta pikiran) yang mencapai rata-rata skor 35,13\%. Pada tes awal (pretest) terdapat 13 siswa yang tuntas, 24 siswa tidak tuntas. Sedangkan pada tes hasil belajar I setelah penerapan model pembelajaran mind mapping (peta pikiran) pada siklus I terjadi peningkatan, yaitu terdapat 22 siswa yang tuntas dan 15 yang tidak tuntas. Untuk memperbaiki kelemahan dan meningkatkan kemampuan menulis cerpen siswa yang telah dicapai pada siklus I, maka pada pelaksanaan siklus II dilakukan perbaikan dengan upaya sebagai berikut. 1) Guru menyusun perencanaan yaitu lebih memotivasi siswa agar lebih bersemangat dalam proses pembelajaran; 2) Memberikan pengakuan dan penghargaan kepada siswa agar lebih semangat, sehingga siswa semakin memahami materi yang diajarkan oleh guru. Masalah-masalah yang ditemukan selama siklus I dijadikan bahan masukan untuk perbaikan-perbaikan dalam merancang perencanaan pada tahap siklus II. 3) Merancang skenario penerapan model pembelajaran mind mapping (peta pikiran) agar lebih mudah dipahami oleh siswa. Hasil belajar siswa setelah diterapkan strategi dan metode pembelajaran pada siklus I telah diketahui bahwa kemampuan menulis cerpen siswa masih tergolong rendah dan belum memenuhi Kriteria Ketuntasan Minimal. Oleh karena itu, dirancang langkah-langkah yang dilaksanakan pada siklus II sebagai usaha untuk meningkatkan kemampuan menulis cerpen dengan memperhatikan kelemahan-kelemahan pada siklus I. Seperti pada siklus sebelumnya, guru mengarahkan siswa untuk duduk kembalai bersama kelompoknya masing-masing yang telah ditetapkan sebelumnya, kemudin guru memberikan masalah yang akan dibahas dalam kelompoknya. Dan pada saat diskusi kelompok berlangsung, guru mengamati dan memantau mereka agar semua aktif. Kemudian guru memberikan tes diakhir pelajaran (postes) untuk melihat tingkat hasil belajar yang akan dicapai siswa pada siklus II.

Setelah dilakukan refleksi pada siklus I dan guru memaparkan pada siswa diawal siklus II kelemahan yang ditemukan pada siklus I maka terjadi perubahan yang cukup signifikan karena siswa lebih paham makna dari setiap kegiatan dan instruksi yang diberikan guru selama proses belajar mengajar berlangsung. Pada Postes Siklus I terdapat 22 (59,45\%) siswa yang tuntas dan 15 (40,54\%) yang tidak tuntas dengan nilai rata-rata skor, sedangkan pada Siklus II terdapat $32(86,48 \%)$ siswayang tuntas dan hanya $5(13,51 \%)$ yang tidak tuntas dengan nilai rata-rata skor maka terjadi peningkatan sebesar 27,03 \%, atau lebih jelasnya lagi dapat dilihat pada Tabel 1. Hasil observasi siklus II menunjukkan adanya peningkatan/perkembangan dalam pelaksanaan yang dilakukan oleh guru. Pada saat melakukan kerja kelompok, kerja sama antaranggota semakin kuat. Hal tersebut dapat dilihat dari adanya peningkatan kemampuan menulis cerpen setiap anggota kelompok.

Tabel 1. Peningkatan Kemampuan Menulis Cerpen Siswa Siklus II

\begin{tabular}{cccccc}
\hline & \multicolumn{2}{c}{ Tuntas } & \multicolumn{2}{c}{ Tidak Tuntas } & Nilai \\
\cline { 2 - 5 } Jenis Test & \multirow{2}{*}{ Jumlah Siswa } & Persentase & Jumlah Siswa & Persentase & Rata-rata \\
\hline Postes I & 22 & $59,45 \%$ & 15 & $40,54 \%$ & 73,51 \\
Postes II & 32 & $86,48 \%$ & 5 & $13,51 \%$ & 84,32 \\
\hline
\end{tabular}

\section{Pembahasan}

Berdasarkan hasil penelitian, dapat diketahui adanya peningkatan kualitas proses pembelajaran dan kualitas hasil menulis cerpen siswa. Peningkatan kualitas proses pembelajaran dapat dilihat dari suasana pembelajaran yang terjadi di kelas. Siswa lebih aktif dan bersungguh-sungguh dalam 
melaksanakan tugas yang diberikan. Selain itu, tidak ada lagi siswa yang bercanda dengan teman sebangku saat proses belajar mengajar sedang berlangsung. Semua siswa tampak sibuk dengan mind mapping yang sedang mereka kerjakan. Hal ini tentunya memberi dampak pada peningkatan kualitas hasil menulis cerpen siswa. Model pembelajaran mind mapping sangat tepat digunakan dalam pembelajaran menulis cerpen. Pemetaan pikiran adalah cara yang baik untuk menghasilkan dan menata gagasan sebelum menulis(Andayani \& -, 2018; Mardika, 2019; Suastika, 2019). Bagian yang paling sulit dalam menulis adalah mengetahui hal apa yang akan ditulis, apa temanya dan bagaimana cara memulainya (Firmansyah, 2021; Ulfah \& Soenarto, 2017). Dengan mind mapping, sebuah tema dijabarkan dalam ranting-ranting yang berupa ide-ide, sehingga menjadi pengembang dalam menulis cerpen. Dalam menulis cerpen, imajinasi dan kreativitas seorang penulis sangat diperlukan untuk mengembangkan ide menjadi sebuah cerita yang menarik. Imajinasi dan kreativitas merupakan ranah kerja otak kanan.

Terjadinya peningkatan hasil menulis cerpen karena Mind mapping dengan gambar, simbol, warna serta kata kuncinya dapat membangkitkan fungsi kerja otak kanan, sehingga memunculkan ide-ide baru yang kreatif dan imajinatif. Penerapan teknik mind mapping dalam pembelajaran menulis cerpen, pertama-tama siswa menuliskan satu kata kunci dari tema yang dipilih di tengah kertas. Tema tersebut kemudian dijabarkan dalam ranting-ranting berupa unsur-unsur intrinsik cerpen yang meliputi amanat, alur, latar, tokoh dan penokohan, sudut pandang dan gaya bahasa. Dengan teknik pembelajaran ini, siswa dituntun untuk membuat perencanaan sebelum menulis cerpen. Bila perencanaan tulisan sering dikenal dengan sebutan kerangka karangan maka dalam mind mapping kerangka karangan tersebut berupa kata kunci yang dilengkapi dengan gambar berwarna yang dipetakan. Selain lebih menarik, kelebihan dari mind mapping adalah siswa dapat menambah kata kunci di mana pun jika di tengah kegiatan menulis, ia mendapatkan ide baru. Peningkatan ini mencakup meningkatnya skor rata-rata pada setiap aspek penilaian dalam menulis cerpen. Terbukti dengan penggunaan model pembelajaran mind mapping siswa lebih aktif selama mengikuti kegiatan belajar mengajar yang berlangsung di kelas. Selain keberhasilan proses, keberhasilan produk juga menjadi perhatian. Dengan penggunaan model pembelajaran mind mapping terjadi peningkatan pada keberhasilan proses dan keberhasilan produk. Penggunaan model tersebut jelas sangat membantu siswa untuk lebih mudah menuangkan ide kreatif dan gagasan mereka ke dalam tulisan (Kiong et al., 2012; Pascual et al., 2016). Temuan ini diperkuat oleh temuan sebelumnya yang menyatakan metode mind mapping mampu meningkatkan minat, motivasi dan hasil belajar siswa (Astuti et al., 2013; Sulfemi, 2019). Selain itu melalui penerapan metode mind mapping terjadi peningkatan keterampilan berbicara (Febiyanti et al., 2020). Dengan menerapkan metode mind mapping siswa lebih mudah memahami materi konsep (Buran \& Filyukov, 2015; Sartono et al., 2018). Mind mapping juga meningkatkan keaktifan siswa (Merchie \& Keer, 2016; Wu \& Chen, 2018). Dari pembahasan tersebut, penerapan model pembelajaran mind mapping dapat peningkatan hasil menulis cerpen. Namun dalam penerapannya model ini membutuhkan waktu yang lama. Imlikasi penelitian ini diharapkan guru dapat menerapkan model pembelajaran ini pada proses pembelajaran. Model ini juga dapat digunakan pada pembelajaran lainnya.

\section{SIMPULAN}

Penerapan model pembelajaran mind mapping dapat meningkatkan kualitas proses pembelajaran menulis cerpen. Pada setiap siklus, terjadi peningkatan perhatian, gairah belajar, keaktifan dan motivasi siswa selama proses pembelajaran. Maka, model pembelajaran mind mapping (peta pikiran) dapat meningkatkan kemampuan menulis cerpen siswa.

\section{DAFTAR RUJUKAN}

Al Hakim, M. F. (2021). Peran Guru dan OrangTua: Tantangan dan Solusi dalam Pembelajaran Daring pada Masa Pandemi COVID-19. Riwayat: Educational Journal of History and Humanities, 1(1), 2332. http://jurnal.unsyiah.ac.id/riwayat/.

Andayani, T., \& -, A. (2018). Improving Students' Ability in Writing Narrative Text by Using Picture Series for the Eight Grade Students of Junior High School. JOALL (Journal of Applied Linguistics \& Literature), 1(2), 1-10. https://doi.org/10.33369/joall.v1i2.4174.

Astuti, N. P. A. W., Ardana, I. K., \& Suardika, I. W. R. (2013). Pengaruh Model Pembelajaran Savi Bermuatan Mind mapping terhadap Hasil Belajar IPA Siswa Kelas IV Sekolah Dasar Gugus III Mengwi. Mimbar PGSD Undiksha, 1(1). https://doi.org/10.23887/jjpgsd.v1i1.1231.

Azis, M. (2019). Analisis Kesulitan Belajar Membaca dan Menulis Permulaan PAUD di Kelompok Bermain Fun Islamic School. AL-Athfaal, 2(2), 100 - 110. https://doi.org/10.24042/ajipaud.v2i2.5927. 
Boerma, I., van der Wilt, F., Bouwer, R., van der Schoot, M., \& van der Veen, C. (2021). Mind mapping during Interactive Book Reading in Early Childhood Classrooms: Does It Support Young Children's Language Competence? Early Education and Development, 1-17. https://doi.org/10.1080/10409289.2021.1929686.

Buran, A., \& Filyukov, A. (2015). Mind mapping Technique in Language Learning. Procedia - Social and Behavioral Sciences, 206. https://doi.org/https://doi.org/10.1016/j.sbspro.2015.10.010.

Dini Rahma Diani, Nurhayati, D. S. (2019). Pengembangan Lembar Kerja Peserta Didik (LKPD) Menulis Cerpen Berbasis Aplikasi Android. Jurnal Bahasa, Sastra, Dan Pengajarannya, 7, 2. https://doi.org/10.20961/basastra.v7i2.37800.

Febiyanti, D., Wibawa, I. M. C., \& Arini, N. W. (2020). Model Pembelajaran Kooperatif Tipe Jigsaw Berbantuan Mind Mapping Berpengaruh terhadap Keterampilan Berbicara. Mimbar Ilmu, 25(2), 282-294. https://doi.org/10.23887/mi.v25i2.26620.

Firmansyah, A. (2021). Penggunaan Media Film Dokumenter dalam Pembelajaran Menulis Puisi. Deiksis: Jurnal Pendidikan Bahasa Dan Sastra Indonesia, 7(2), 60-65. https://doi.org/10.33603/deiksis.v7i2.3373.

Fitriani, S. A., \& Nurchasanah. (2017). Keefektifan Bahan Ajar Menulis Teks Prosedur Kompleks dengan Pendekatan Kontekstual untuk Siswa Kelas X SMK. Jurnal Pendidikan: Teori, Penelitian, Dan Pengembangan, 2(12), 1683-1691. https://doi.org/10.17977/jptpp.v2i12.10333.

Kiong, T. T., Yunos, J. M., Mohammad, B., Othman, W., Heong, Y. M., \& Mohamad, M. M. (2012). The Development and Implementation of Buzan Mind Mapping Module. Procedia - Social and Behavioral Sciences, 64. https://doi.org/10.1016/j.sbspro.2012.11.464.

Mardika, T. (2019). Analisis Faktor-Faktor Kesulitan Membaca Menulis dan Berhitung Siswa Kelas 1 Sd. Dinamika Jurnal Ilmiah Pendidikan Dasar, 10(1), 28-33. https://doi.org/10.30595/dinamika.v10i1.4049.

Maulina, H., Intiana, S. R. H., \& Safruddin, S. (2021). Analisis Kemampuan Menulis Cerpen Siswa Sekolah Dasar. Jurnal Ilmian Profesi Pendidikan, 6(3), 482 - 486. https://doi.org/10.29303/jipp.v6i3.276.

Merchie, E., \& Keer, H. Van. (2016). Mind Mapping as a Meta-Learning Strategy: Stimulating PreAdolescents' Text-Learning Strategies and Performance? Contemporary Educational Psychology, 46. https://doi.org/10.1016/j.cedpsych.2016.05.005.

Nugraheni, I. (2019). Media Buku Cerita untuk Meningkatkan Kemampuan Membaca dan Menulis Siswa Kelas IV Sekolah Dasar. Journal of Education, 4(3), 322-329. https://doi.org/10.17977/jptpp.v4i3.12085.

Nuzulia, D. (2016). Pengaruh Penggunaan Media Diorama Papercraft terhadap Kemampuan Menulis Cerpen Siswa Kelas X SMA Negeri 10 Palembang. Jurnal Ilmu Kependidikan, 4(1). https://doi.org/10.31851/wahanadidaktika.v14i1.564.

Pascual, M., Miñana, E. P., \& Giacomello, E. (2016). Integrating Knowledge on Biodiversity and Ecosystem Services: Mind-mapping and Bayesian Network Modelling. Ecosystem Services, 17. https://doi.org/10.1016/j.ecoser.2015.12.004.

Putra, I. K. D. A. S., Margunayasa, I. G., \& Wibawa, I. M. C. (2017). Pengaruh Model Pembelajaran Inkuiri Terbimbing Berbantuan Peta Pikiran terhadap Hasil Belajar IPA Kelas V SD. Jurnal Pendidikan, 5(2), 1-10. https://doi.org/10.23887/jjpgsd.v5i2.10711.

Rahmadani, N. (2019). Peningkatan Keterampilan Menulis Permulaan melalui Penerapan Metode Struktur Analitik Sintetik (SAS) Di Kelas I SDN 61 Tondok Alla Kecamatan Telluwanua Kota Palopo. Journal of Teaching Dan Learning Research, 1(1), 33-40. https://doi.org/10.24256/jtlr.v1i1.586.

Sartono, N., Komala, R., \& Dumayanti, H. (2018). Pengaruh Penerapan Model Reciprocal Teaching Terintegrasi Mind mapping terhadap Pemahaman Konsep Siswa pada Materi Filum Arthropoda. BIOSFER : Jurnal Pendidikan Biologi, 9(1). https://doi.org/10.21009/biosferjpb.9-1.4.

Satriana, M., Buhari, M. R., Makmun, M., Maghfirah, F., Haryani, W., Wahyuningsih, T., Wardana, H., Sagita, A. D. N., Oktamarina, L., \& Bakar, A. A. (2021). Persepsi Guru PAUD terhadap Pembelajaran Online: Fenomena Masa Pandemi Covid-19. Jurnal Obsesi : Jurnal Pendidikan Anak Usia Dini, 6(1), 362373. https://doi.org/10.31004/obsesi.v6i1.1353.

Suastika, N. S. (2019). Problematika Pembelajaran Membaca dan Menulis Permulaan di Sekolah Dasar. Adi Widya: Jurnal Pendidikan Dasar, 3(1), 57. https://doi.org/10.25078/aw.v3i1.905.

Sulfemi, W. B. (2019). Model Pembelajaran Kooperatif Mind Mapping Berbantu Audio Visual dalam Meningkatkan Minat, Motivasi dan Hasil Belajar IPS. Jurnal PIPSI Uurnal Pendidikan IPS Indonesia), 4(1), 13. https://doi.org/10.26737/jpipsi.v4i1.1204.

Sunarsih, E. (2016). Penerapan Model Pembelajaran Project Based Learning (Pjbl) Untuk Meningkatkan Keterampilan Menulis Teks Berita Pada Siswa Kelas VIII SMP Negeri 16 Singkawang. JP-BSI Uurnal Pendidikan Bahasa Dan Sastra Indonesia, 1(2), 65 - 67. https://doi.org/10.26737/jp- 
bsi.v1i2.92.

Susilo, S. V., \& Ramdiati, T. (2019). Penerapan Model Multiliterasi untuk Meningkatkan Keterampilan Menulis Karangan Persuasi pada Mata Pelajaran Bahasa Indonesia Di Sekolah Dasar. Jurnal Cakrawala Pendas, 5(1). https://doi.org/10.31949/jcp.v5i1.1199.

Ulfah, D. M., \& Soenarto, S. (2017). Pengaruh Penggunaan Media Video dan Gambar terhadap Keterampilan Menulis Kelas V. Jurnal Prima Edukasi, 5(1), $22 \quad$ - 34. https://doi.org/10.21831/jpe.v5i1.7693.

Wu, T.-T., \& Chen, A.-C. (2018). Combining E-Books with Mind Mapping in A Reciprocal Teaching Strategy for A Classical Chinese Course. Computers \& Education, 116. https://doi.org/10.1016/j.compedu.2017.08.012.

Yamtinah, Marhaeni, A. A. I. N., \& Lasmawan, I. W. (2021). Pengembangan Instrumen Keterampilan Menulis Karangan dan Kemampuan Berpikir Kreatif pada Materi Karangan Narasi Siswa Kelas IV Sekolah Dasar. PENDASI: Jurnal Pendidikan Dasar Indonesia, 5(1), 94-104. https://doi.org/10.23887/jurnal_pendas.v5i1.262. 